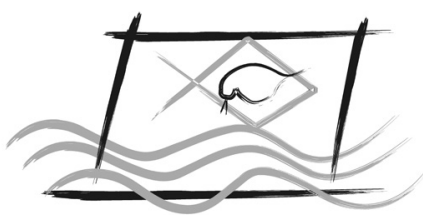

ECOTOX - BRASIL

\title{
Toxicity of Amoxicillin and Erythromycin to Fish and Mosquitoes
}

\author{
El-NahHal Yasser \& El-Dahdouh Nabila \\ Department of Enverionmental and Earth Science. Faculty of Science, The Islamic University-Gaza, Gaza Strip, Palestine.
}

(Received November 27, 2014; Accept April 22, 2015)

\begin{abstract}
This study characterized the toxicity of Amoxicillin (AM), Erythromycin (ER) and Endosulfan (EN) to fish and mosquito larvae obtained from a certified fish farm and from Wadi Gaza. The acute toxicity tests were determined by calculating mortality percentage of fish and mosquitoes through a gradient concentration of the tested compounds. Mortality percentage, exposure time, $\mathrm{LC}_{50}$ and $\mathrm{LT}_{50}$ were taken as indicators of toxicity. The results showed that $\mathrm{AM}$ was the potent compound against fish with $\mathrm{LC}_{50}$ value lower that EN. Toxicity to fish is in the following order: $\mathrm{AM}>\mathrm{EN}>\mathrm{ER}$ whereas the toxicity to mosquitoes is in the following order: ER $>$ EN $>$ AM. Fish are more sensitive to AM than mosquitoes whereas mosquitoes are more sensitive to ER than fish. The interesting outcome of the study is the calculated $\mathrm{LC}_{50}$ values are far below the concentration found in different water systems. Mixture toxicity of the tested antibiotics indicates antagonistic effect on both fish and mosquitoes.
\end{abstract}

Key-words: Antibiotics, Fish, Mosquitoes, $\mathrm{LC}_{50}$, Toxicity.

\section{INTRODUCTION}

Antibiotics are pharmaceuticals widely used not only for human and veterinary medication but also for livestock and aquaculture growth promotion (Sarmah et al.,2006). After normal application of the antibiotics, 50 to $90 \%$ of them and/ or their metabolites are eliminated from the body, mainly through urine and feces, which then enter the environment indirectly through sewage treatment plants or directly through fertilizer application to agricultural land (Schlusener \& Bester, 2006).

Amoxicillin (AM) and Erythromycin (ER), act by inhibiting the synthesis of bacterial cell wall and/or cross-linkage between the linear peptidoglycan polymer chains that make up a major component of the cell walls of both Gram-positive and Gramnegative bacteria (Mozayani \& Raymon, 2004).

Antibiotics may reach the drinking water and cause extreme allergy to some sensitive species including human beings. Moreover, contamination of water and soil systems with low concentrations of antibodies may create bacteria resistant to antibiotics and create public health problems. For instance, Poonia et al. (2014) reported that most bacteria isolated from natural sources of water from rural areas of East Sikkim were found to be resistant to commonly used antibiotics including AM and ER. Moreover, Mulamattathil et al. (2014) isolated environmental bacteria from surface and drinking water in Mafikeng, South Africa, and found all organisms resistant to AM and ER. In a different study Braschi et al. (2013) investigated the persistence and degradation of $\beta$-lactam antibiotics in the soil and water environment and found several degradation products in soils at different water potentials indicating resistant species. Distribution and occurrence of antibiotics in the environmental components have also been studied. For instance, Tong et al. (2014) studied the occurrence of 19 antibiotics including ER in surface water and groundwater samples collected from Shahu County of Jianghan Plain, central China, in autumn (dry season) and spring (wet season). They reported high concentration of all test antibiotics. Moreover, Liu et al. (2014) investigated the distribution, bioconcentration, metabolism, and effects of ER in crucian carp (Carassius auratus). They showed that a maximum tissue concentration occurred in the muscle and that the bioconcentration factor (BCF) of 72.2 was lower than the theoretical BCF of 90.4 calculated from the octanol-water coefficient of ER. 
Nevertheless, few studies investigated the toxic effects of antibiotics in the environment. For instance, Oplinger \& Wagner (2012) evaluated the effectiveness of antibiotics (ER, streptomycin, \& a penicillin-streptomycin mixture) against F. psychrophilum. They showed that ER concentrations up to $2,000 \mathrm{mg} \mathrm{L}^{-1}$ for $15 \mathrm{~min}$ were also ineffective. Moreover, Ji et al. (2012) evaluated the toxicity of chlortetracycline, ox tetracycline, sulfamethazine, sulfathiazole, and ER using Daphnia magna and fish. They reported considerable effects on the tested organism and revealed the necessity of further long-term investigation. Furthermore, Wang and Gardinali (2012) analyzed different environmental samples and found sulfamethoxazole and ER residues in reclaimed water. In a different study, Gao et al. (2012) investigated the occurrence, distribution and bioaccumulation of 22 antibiotics, in the Haihe river, surface water, sediment and fish samples. They found ER and other antibiotics in all surface water samples. Moreover, Carballeira et al. (2012) studied the toxicity of AM on fish and found similar sensitivities to all substances tested. In addition, Park et al. (2010) detected AM in fish tissue after the $3^{\text {rd }}$ day of spiking in water. Liu et al. (2012) studied the toxicity AM and microcystins against algae and found that Spiramycin is more toxic to $M$. aeruginosa than AM according to their $\mathrm{EC}_{50}$ values. He et al. (2012) investigated the multi-biomarker responses in fish from two typical marine aquaculture regions of South China. Tyczkowska et al. (2012) found beta-lactam antibiotics in bovine milk using multi-residue analytical method. Li et al. (2012) detected antibiotic residues in water samples and correlated it with the detrimental effect on ecological and human health due to bacterial resistance. Liu et al. (2011) determined AM and penicillin $\mathrm{G}$, and their major metabolites in bovine milk by ultra-high-performance liquid chromatography in tandem with mass spectrometry. Ebert et al. (2011) investigated growth inhibition of fluoroquinolone enrofloxacin and ciprofloxacin on four photoautotrophic aquatic species. Christensen et al. (2006) studied the mixture toxicity of aquaculture antibiotics ox tetracycline, oxolinic acid, ER, florfenicol, and flumequine and found synergistic effects when combinations of ER and ox tetracycline were tested on activated sludge microorganisms.

Large quantities of AM and ER are being used in Gaza strip in the human and/or animal health sectors (MOH, 2012). Fish farming breeders claimed high fish mortality after antibiotic application to control fish disease. Moreover, many dead fish of different sizes were found on the coastal area close to Wadi Gaza that is an indispensable part of natural life in Palestine and has an interesting history and rich biodiversity in terms of fauna and flora probability due to contamination of antibiotics and/or pesticides (Abd Rabou, 2005). The presence of those antibiotics or pesticides threating Wadi Gaza's biodiversity. Accordingly, the authors designed this study to investigate the toxicity to fish and mosquitoes using concentrations far below the U.S. official tolerance for AM/ER $\left(10 \mathrm{mg} \mathrm{Kg}^{-1}\right)$ in milk and uncooked edible tissue of cattle (U.S. Code of Federal Regulations, 1991) and the concentrations found in water (Oliveira et al., 2013; Gozlan et al., 2013), wastewater (Novo et al., 2013; Lamm et al., 2009), milk (Liu et al., 2011) and/or fish samples (Smith et al., 2009; Wang et al., 2009). Moreover the authors investigated the toxicity of EN to the tested organism to estimate the relative toxicity of AM and ER.

\section{MATERIALS AND METHODS}

\section{Materials}

Technical amounts of antibiotics (AM and ER) were purchased from Ramalla Medical Drug Company, Ramalla, Al-Beera, WB, Palestine, whereas EN, a standard toxic substance, was purchased from Sigma, Germany and used in this study to compare the toxicity of AM and ER to fish and mosquitoes. Some physicochemical properties of these compounds are presented in Table1 and their chemical structure in Figure 1. The tested organisms are Juvenile goldfish (Tilapia nilotica) and mosquito larvae (Culex pepans) were obtained from local certified fish farming breeding sites and from Wadi Gaza. The rationale in selecting two different organisms is that each represents a different position in the food chain in the eco-system and has different sensitivity to environmental pollution (OECD, 1992).

\section{Preparation of stock solution}

About $100 \mathrm{mg}$ of ER was dissolved in $25 \mathrm{~mL}$ of methanol. One $\mathrm{ml}$ methanol was transferred to a one liter volumetric flask and completed with distilled water to the mark and used as stock solution for the necessary dilutions.

A series of concentrations ranging from $0-200 \mu \mathrm{g} \mathrm{L} \mathrm{L}^{-1}$ was prepared and tested. The same procedure was followed for the case of EN whereas AM was dissolved in $25 \mathrm{~mL}$ of acetone because AM does not dissolve in methanol, and the same steps as in ER were repeated for AM.

\section{Breeding and acclimatization of fish and mosquitoes}

Acclimatization of fish and mosquitoes was done according to the method previously described (OECD, 1992).

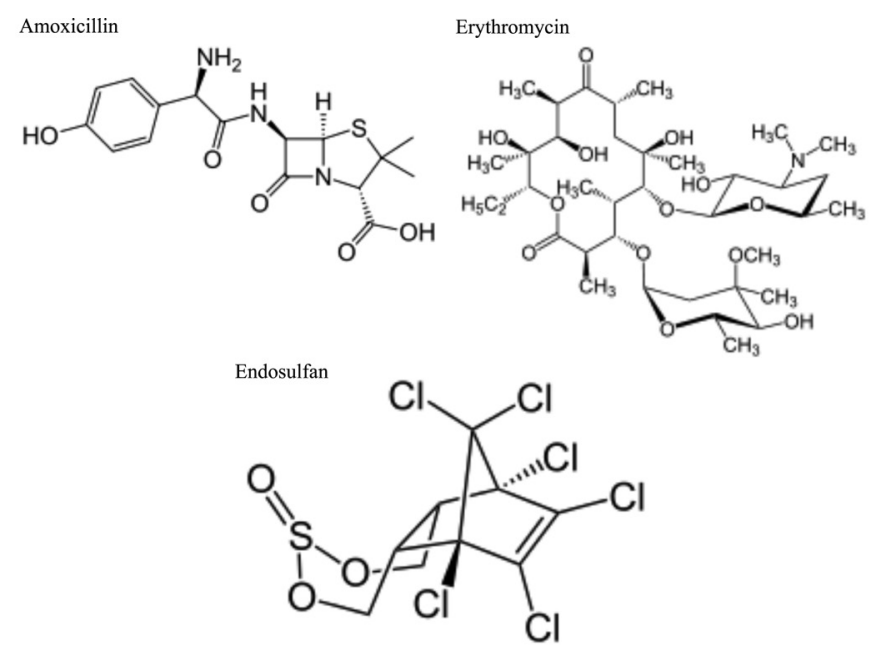

Figure 1. Chemical structure of the tested compounds. 
In this procedure the larvae of fish and mosquitoes were bred under laboratory conditions with 12 hours of light followed by 12 hour of dark, for two weeks before starting the toxicity tests. The temperature of the laboratory was controlled at $25 \pm 2{ }^{\circ} \mathrm{C}$. The dead fish or mosquitoes were removed from the breeding cage. The average weight of a single fish was $20 \pm 1 \mathrm{~g}$ and average length was $4 \pm 0.5 \mathrm{~cm}$. The fish were held in a 500 liter plastic barrel equipped with an aeration pump to supply oxygen to the water. The water had the following characteristic: pH: $7.5 \pm 0.5$, desalinated Fish were fed on daphnia. During the test five fish were put in each glass aquaria $(10 \times 15 \times 20 \mathrm{~cm})$ half filled with the test solutions that were presaturated with oxygen. The dissolved oxygen was tested every 12 hours using the dissolved oxygen meter. The temperature was also tested every 12 hours to ensure suitable conditions during the test. For mosquitoes, acclimatization depends on the development of $1^{\text {st }}$ instars larvae to the $2^{\text {nd }}$ instars.

\section{Toxicity Test on Fish}

Two days before testing the fish larvae were put in deionized water with no feed for 96 hours, static acute toxicity test (OECD, 1984). In this test, fish were exposed to five gradient concentrations up to the solubility limit on water to determine the concentration response curve for AM, ER and EN on fish under laboratory conditions. The experiments included positive and negative control samples, the positive contained $50 \mu \mathrm{L}$ of methanol (solvent control) whereas the negative did not include methanol. Mortality was recorded every 24 hours for 96 hours.

\section{Toxicity test on mosquitoes}

The tests were performed in $20 \mathrm{~mL}$ capacity glass tubes. Ten $\mathrm{mL}$ of desalinated water containing five mosquito larvae were transferred to each glass tube. Appropriate amounts representing gradient concentrations ranging from $0-160 \mu \mathrm{g}$ $\mathrm{L}^{-1}$ were spiked in the test tubes. Each test included five series of concentrations with four replicates each in addition to positive and negative control treatments as mentioned above under the recommended conditions of the OECD (1992). The experiments were kept at a temperature of $22^{\circ} \pm 1^{\circ} \mathrm{C}$, $\mathrm{pH} 7.5 \pm 0.5$, and $12 / 12$ dark/light photoperiod. The number of dead larvae in each tube was observed and registered every 24 hours for 48 hours.

\section{Calculation of toxicity and statistical analysis}

Percent mortality of fish and mosquito larvae were taken as indicators of toxicity of the tested compound in single and/ or binary mixture. Calculation of mortality percentage was done using equation 1 according El-Nahhal et al. (1998) with a slight modification:

$$
\text { Mortality }=100 * \frac{(L c-L t)}{L c}
$$

where Lc and Lt are the number of live organisms in the control and the treated samples respectively. Percent mortality was regressed versus concentration and converted to a log scale to calculate the $\mathrm{LC}_{50}$ values, furthermore the mortality percentage was also regressed versus time to calculate $\mathrm{LT}_{50}$.

Relative toxicity (RT) was calculated according to equation 2.

$$
R T=\frac{L C t_{50}}{L C S_{50}}
$$

where $\mathrm{LCt}_{50}$ and $\mathrm{LCs}_{50}$ are the lethal concentration of the tested and the standard compounds, respectively. A value of RT equal to or less than 1 indicates higher toxicity whereas a value above 1 indicates lower toxicity than the standard toxic substance.

T-test was used to detect variances among treatments. Fish and mosquito tests include three replicates of each concentration in addition to positive and negative control samples. The positive control includes $50 \mu \mathrm{L}$ methanol. Toxicity of mixtures was calculated based on mortality percentage and toxic units available in the solution. According to a previous report (Sprogue \& Ramsay, 1965), toxic unit was calculated as: Toxic unit = actual concentration in solution/ lethal threshold concentration.

\section{RESULTS}

\section{Single toxicity test on fish}

Concentration response relationships of AM, ER and EN on fish and mosquito mortality are shown in Figure 2.

It is obvious that mortality percentage increased rapidly as the concentration of AM, ER, and EN increased in the solution and reached $50 \mu \mathrm{g} \mathrm{L}^{-1}$. Then a slight increase in mortality percentage above $50 \mu \mathrm{g} \mathrm{L}^{-1}$ was observed in fish whereas in the mosquito tests, considerable in mortality percentage was observed as the concentration increased in the solution up to $160 \mu \mathrm{g} \mathrm{L}^{-1}$.

Moreover, the results presented in Figure 2 clearly demonstrate that EN at a concentration below $10 \mu \mathrm{g} \mathrm{L}^{-1}$ resulted in less than 10 percent fish mortality. This concentration can be named No-Observed Effects Concentration (NOEC). This point was not detected in AM and ER tests.

Converting the data in Figure 2 to $\log$ scales enabled the calculations of $\mathrm{LC}_{50}$ values, which are $35.72,242.7$, and 89.32 $\mu \mathrm{g} \mathrm{L}^{-1}$ on fish test; the values for mosquito test are 107.6, 60.2, and $63.3 \mu \mathrm{g} \mathrm{L}^{-1}$ for AM, ER and EN respectively. In addition strong positive associations with high correlation coefficients $\left(R^{2}\right)$ were observed (Table 2).

Furthermore, calculating the RT (Eq. 2) indicates a lower value of AM than EN, whereas ER has a higher value than EN on fish. For mosquitoes, the RT values for AM and ER are 1.7 and 0.95 respectively. This indicates the potentially higher toxicity of ER than the other antibiotics. The interesting results are that the RT value of ER, which is nearly half that of $\mathrm{AM}$, indicates greater toxicity of ER to mosquitoes. 

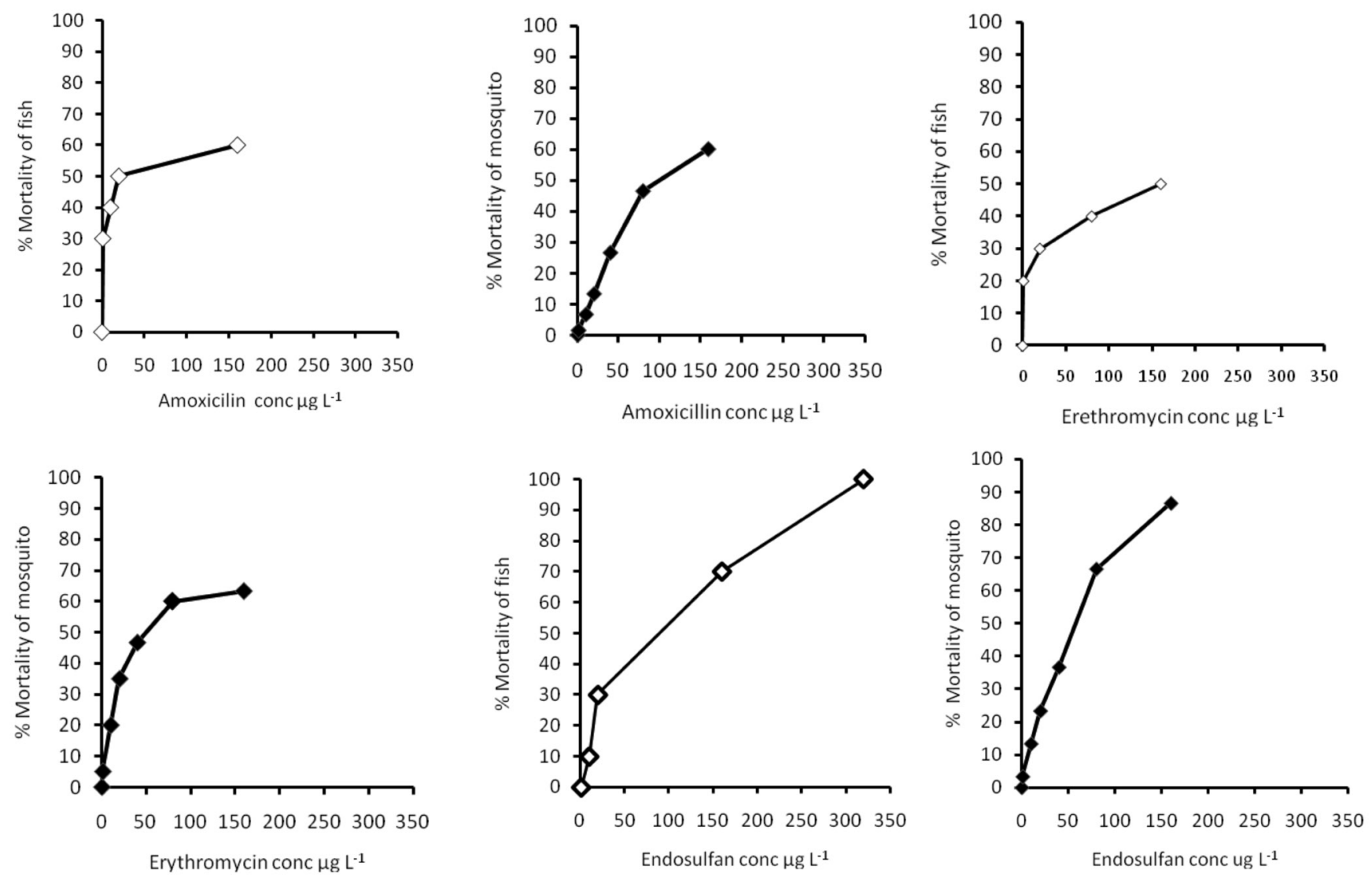

Figure 2. Concentration response relationships of Amoxicillin, Erythromycin and Endosulfan on fish and mosquito mortality. Mortality percentage was recorded after 48 and $96 \mathrm{~h}$ for mosquito and fish respectively.

\section{Effect of time on toxicity}

Time response relationships of AM, ER, and EN concentrations on fish and mosquitoes are shown in Figure 3. The data clearly demonstrate a progressive relationship between mortality percentage and length of exposure. Linear regression analysis indicated a strong positive association with a high value of $\mathrm{R}^{2}$.

To compare the toxicity according to length of exposure, we regressed the data in Figure 3 to a linear mode. This enabled the calculation of the length of exposure required to kill 50 percent of fish or mosquitoes at the tested concentration. The calculated values are presented in Table 2. Statistical analysis of mortality percentage versus length of exposure obtained by the three tested compounds against fish show different p-values $(0.08-0.14)$.

\section{Toxicity of mixture}

Dose response relationships of AM and ER mixture on fish and mosquito are shown in Figure 4. The mixture showed no mortality rate in fish whereas high mortality rates were observed in mosquitoes.

Moreover, mortality percentage of mosquitoes increased as the concentration of the mixture increased in the solution. However, the maximum mortality percentage value obtained at the highest concentration did exceed $60 \%$. This value is equal to or below the mortality percentage value obtained from mosquitoes in the single toxicity tests (Fig 2).

\section{DISCUSSION}

AM and ER (Fig. 1) are antibiotics widely used to treat bacterial infections in the human and veterinary sectors. AM acts by inhibiting the synthesis of bacterial cell wall whereas ER is a macrolide antibiotic and acts as a bacteriostatic that inhibits growth of bacteria. Moreover, EN is an organochlorine insecticide, used in this study as a standard toxic substance to fish and mosquitoes to calculate the relative toxicity of AM and ER. They are solid at room temperature, and have different chemical structures and physical properties.

The results presented in Figure 2 clearly demonstrate the potential toxicity of AM, ER, and EN to fish and mosquitoes. EN, a standard toxic substance, showed high toxicity to both cases. In fact, EN is classified as extremely toxic substance according to WHO (Tomlin, 2000). Our results agree with Echeverría-Sáenz et al. (2012) and Bauer et al. (2013) who found increased fish mortality due to high levels of insecticides in water.

Moreover, the steep increase in mortality percentage on fish and mosquitoes below $50 \mu \mathrm{g} \mathrm{L}^{-1}$ (Fig. 2) suggests that the majority of the tested population is sensitive to low concentrations of AM and ER, while the remainder are tolerant, 

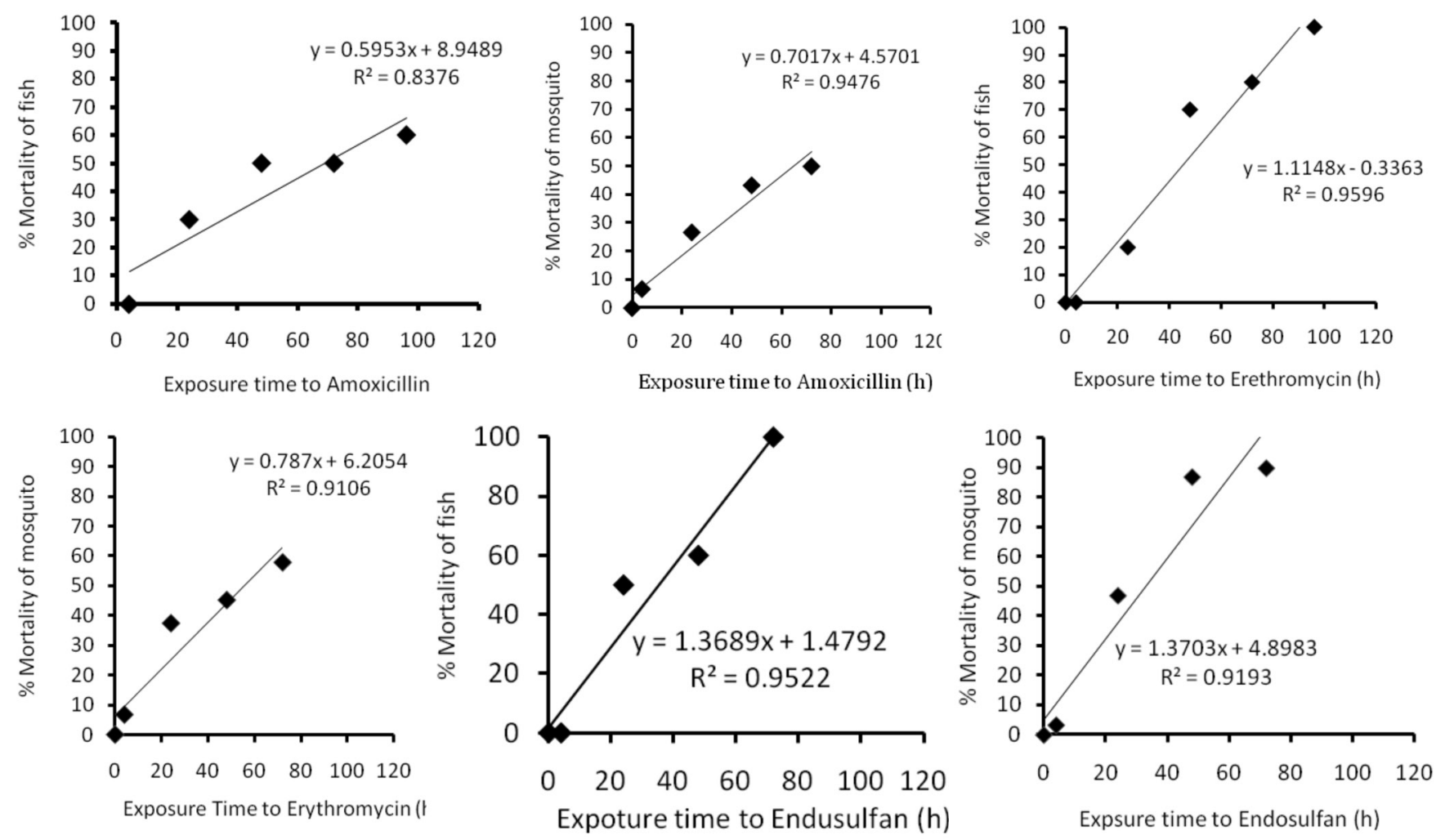

Figure 3 Time response relationships of diluted concentrations ER, AM and EN on fish and mosquito mortality. Mortality percentage was recorded at a certain concentration of each compound $(0.08 \mathrm{mg} / \mathrm{l})$ overtime.

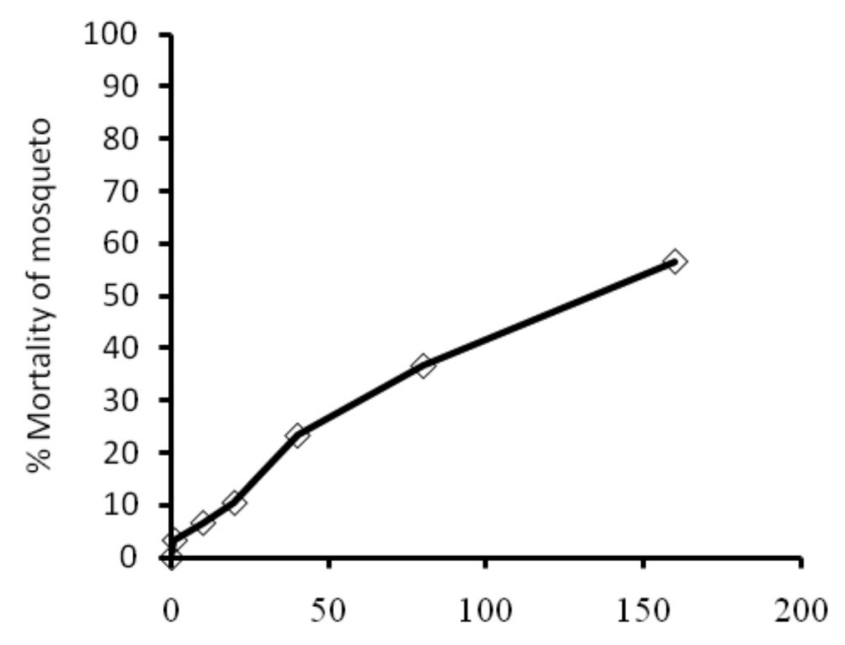

Concentration of Amox+Erethro $\mu \mathrm{g} \mathrm{L} \mathrm{L}^{-1}$

Figure 4. Concentration response relationship of Amoxicillin and Erythromycin Mixture on mosquito larvae. Mortality percentage was recorded after $48 \mathrm{~h}$.

accordingly mortality percentage reached a plateau with the fish and mosquito tests. This tolerance may be attributed to the fact that their exposure to sub-lethal concentrations of AM or ER in the eco-system contributes to the development of a gene resistant to antibiotics. This suggestion is supported by the results of Yi et al. (2014) who investigated the prevalence of resistant genes against $\beta$-lactams in 119 fish strains and reported that a large number $(99.2 \%)$ of the present fish strains were resistant to one or more $\beta$ - lactams including ceftiofur, AM-clavulanic acid, ampicillin, piperacillin and cefpodoxime. More support for our hypothesis can be found in Oliveira et al. (2013), who investigated the the sub-lethal effects of oxytetracycline and amoxicillin on zebrafish development and biomarkers and revealed that AM caused premature hatching ( $48 \mathrm{~h}-\mathrm{EC}_{50}=132.4 \mathrm{mg} \mathrm{L}^{-1}$ ) whereas oxytetracycline cause delayed hatching of embryos (72 h-EC $\mathrm{E}_{50}=127.6 \mathrm{mg} \mathrm{L}^{-1}$ ).

In addition, the similarity of the toxicity curves in Figure 2 suggests similar sensitivity to the tested compound. This finding agrees with Carballeira et al. (2012), who investigated the toxicity of AM and other antibiotics to embryos of two species of sea urchin (Paracentrotus lividus \& Arbacia lixula) and found that both species showed similar sensitivities to all substances tested.

Furthermore, the toxicity curve of EN to fish and mosquito is nearly similar, these suggest similar responses by the tested organisms. As mentioned above EN has the same mode of action on fish and mosquitoes (Tomlin, 2000).

The calculated $\mathrm{LC}_{50}$ values (Table 2 ) from the experimental results in Figure 2 clearly show the lowest value of AM on fish test. The RT calculation indicates that AM has lower value than EN, regardless of the fact that the apparent toxicity of EN is high and mortality reached 100 percent in both cases.

An interesting finding is the high toxicity of AM to fish, and of ER to mosquitoes. The high values of $\mathrm{R}^{2}$ indicate 
the strong positive association. The toxicity to fish has the following order: $\mathrm{AM}>\mathrm{EN}>\mathrm{ER}$.

Our results are in agreement with previous reports (Ebert et al., 2011; Liu et al., 2012).

The variations in the toxicity of the tested compounds may be explained by the fact that the tested compounds have different values of $\mathrm{K}_{\text {ow }}$. For instance AM has high $\mathrm{K}_{\mathrm{ow}}$ value which enables it to be partitioned rapidly from the aquatic phase to the hydrophobic phase (fish). This explanation can be supported by the results of Liu et al. (2014) who emphasized the importance of $\mathrm{K}_{\text {ow }}$ on bioaccumulation or biodegradation of antibiotics in fish. Statistical analysis of mortality percentage obtained for the three tested compounds against fish does not show any significant differences between ER and AM. However, comparison with EN showed significant differences. P-values ranged between 0.03-0.000.

Moreover, the increased mortality percentage due to increase in the length of exposure (Fig. 3) can be explained by the relation to $\mathrm{K}_{\mathrm{ow}}$ and Henry constant of the tested compound (Table 1). The high values of $\mathrm{K}_{\mathrm{ow}}$ for EN and ER indicate the high potential of movement of these compounds from water to fish. As time increased from four hours to 96 hours, high fraction of ER and EN accumulate in fish tissue and caused mortality. The low $\mathrm{K}_{\mathrm{ow}}$ value of AM reduces the potential of bioaccumulation in fish tissues, accordingly, the mortality of fish may take a longer time than other cases. This explanation is also supported by the results of Liu et al. (2014). The calculated $\mathrm{LT}_{50}$ values are presented in Table 2. Furthermore, the shape of the toxicity curve (Fig. 2) is nearly similar which suggests that the tested organisms have similar sensitivity to AM, ER and EN. An important finding of the study is that the calculated $\mathrm{LC}_{50}$ values are far below the concentrations detected in several water systems (Oliveira et al., 2013; Gozlan et al., 2013; Novo et al., 2013; Lamm et al., 2009) found in edible parts of fish (Smith et al., 2009; Wang et al., 2009), milk (Liu et al., 2011), and/or U.S. official tolerance for AM/ER (10 $\left.\mathrm{mg} \mathrm{Kg}^{-1}\right)$.

The presented toxicity parameters in Table 2, clearly show that $\mathrm{EN}$ has the lowest $\mathrm{LT}_{50}$ value $(35 \mathrm{~h})$ whereas AM and ER have $\mathrm{LT}_{50}$ value nearly 2 and 4 times higher than EN. This is in agreement with $\mathrm{K}_{\text {ow }}$ values (Table 1). This suggests that EN has a fast knock-down effect whereas AM and ER have a slow knock-down effect on fish or mosquitoes. The high $\mathrm{R}^{2}$ values of all cases indicate a strong positive association.

Our results agree with Liu et al. (2012), who demonstrated the influences of two antibiotics on the eco-systems activity.

Table 1. Physicochemical properties of Amoxicillin ,Erythromycin and Endosulfan.

\begin{tabular}{|c|c|c|c|}
\hline Properties & $\mathrm{AM}$ & ER & EN \\
\hline MW & 365.40 & 733.93 & 406.93 \\
\hline Solubility in water $\mathrm{mg} \mathrm{L}^{-1}$ & 3430 & 1.44 & 0.32 \\
\hline $\mathrm{K}_{\mathrm{OW}}$ & 0.9 & 2.8 & 3.5 \\
\hline Hennery constant & $2.73 * 10^{-19}$ & - & 1.48 \\
\hline $\mathrm{pKa}$ & 3.39 & 8.9 & - \\
\hline
\end{tabular}

Comparing the $\mathrm{LT}_{50}$ values of the tested compounds against fish (Table 2), one can realize the highest $\mathrm{LT}_{50}$ value of ER. This suggests a slower knock-down effect of ER on fish than $\mathrm{AM}$ and $\mathrm{EN}$. Moreover, the $\mathrm{LC}_{50}$ values of ER is several times higher than AM and EN (Table 2). This may also lengthen the time required to kill $50 \%$ of the tested fish at lower concentrations. Furthermore, EN has the lowest $\mathrm{LT}_{50}$ value. The explanation of these results is related to the solubility limit of ER in water which is several times lower than those of AM and EN (Table 1), in addition to the fact that ER has a high $\mathrm{K}_{\mathrm{ow}}$ value. These data make the partitioning process of ER from water to fish longer than those of AM and EN. These data agree with the results presented in Figure 3.

Statistical analysis of mortality percentage versus length of exposure obtained by the three tested compounds against fish show different p-values (0.08-0.14).

In the case of mosquitoes, the data presented in Table 2 clearly demonstrated that $\mathrm{ER}$ has the lowest $\mathrm{LC}_{50}$ value among all cases, indicating the highest toxicity on mosquitoes. It is well known that AM and ER have a different mode of action on bacteria. This different mode of action also becomes obvious in fish and mosquito tests. Our results agree with Milam et al. (2005). Statistical analysis of mortality percentage versus concentrations shows significant differences among the three tested compounds. P-values ranged between 0.0130.04. This indicates different responses of mosquitoes to the tested compounds. The explanation of these results is given above, in addition to the fact that the tested compounds have different physicochemical properties (Table 1). Comparing the $\mathrm{LC}_{50}$ values (Table 2), the toxicity to fish has the following order: $\mathrm{ER}>\mathrm{EN}>\mathrm{AM}$. The different $\mathrm{LC}_{50}$ values of the tested compounds indicate different sensitivity and response of the tested organism.

The $\mathrm{LT}_{50}$ value (Table 2) of AM is the highest value among all tested compounds. This clearly indicates that the response time between mosquitoes and AM is longer than with ER and EN. Furthermore, EN has the lowest $\mathrm{LT}_{50}$ value among all tested cases. The explanation of these results is similar to that given above.

Comparison of $\mathrm{LT}_{50}$ values of fish and mosquitoes shows that the values are close to each other except for ER, which has $\mathrm{LT}_{50}$ value on fish 2.55 times higher than on mosquitoes. The explanation of this variation is that bioaccumulation of the tested compound on fish tissues depends on various factors such as size and, fat content of the subject and $\mathrm{K}_{\text {ow }}$ of the tested compound. In the presented case, fish larvae is larger than mosquito larvae and has more fat, accordingly ER takes longer to bioaccumulate in fish tissues to cause a lethal effect. This explanation is supported by the results of El-Amrani et al. (2012), who found different bioaccumulation modes of pesticides in Zebrafish eleutheroembryos.

The data presented in Figure 4 clearly demonstrated the considerable toxicity against mosquitoes, whereas no mortalitys were reported with fish. This indicates antagonistic effects of the tested antibiotics on fish. Regardless of the 
Table 2. $\mathrm{LC}_{50}, \mathrm{RT}, \mathrm{LT}_{50}, \mathrm{R}^{2}$ and regression equations on fish and mosquito tests.

\begin{tabular}{lcccccc}
\hline \multirow{2}{*}{ Parameter } & \multicolumn{3}{c}{ Fish } & \multicolumn{3}{c}{ Mosquito } \\
\cline { 2 - 7 } & $\mathrm{AM}$ & $\mathrm{ER}$ & $\mathrm{EN}$ & $\mathrm{AM}$ & $\mathrm{ER}$ & $\mathrm{EN}$ \\
\hline $\mathrm{LC}_{50}\left(\mu \mathrm{g} \mathrm{L}^{-1}\right)$ & 35.72 & 242.7 & 89.32 & 107.6 & 60.2 & 63.3 \\
$\mathrm{RT}$ & 0.4 & 2.72 & 1 & 1.7 & 0.95 & 1 \\
$\mathrm{R}^{2}$ & 0.97 & 0.97 & 0.92 & 0.99 & 0.96 & 0.99 \\
$\mathrm{Re}$ Eq & $\mathrm{y}=0.14 \mathrm{X}+1.48$ & $\mathrm{y}=0.17 \mathrm{X}+1.29$ & $\mathrm{y}=0.6 \mathrm{X}+0.55$ & $\mathrm{y}=0.76 \mathrm{X}+0.15$ & $\mathrm{y}=0.53 \mathrm{X}+0.76$ & $\mathrm{y}=0.66 \mathrm{X}+0.51$ \\
$\mathrm{LT}_{50}(\mathrm{~h})$ & 69 & 132 & 35 & 63.47 & 51.76 & 33.72 \\
$\mathrm{R}^{2}$ & 0.84 & 0.94 & 0.95 & 0.99 & 0.97 & 0.96 \\
$\operatorname{Re} \mathrm{Eq}$ & $\mathrm{Y}=0.6 \mathrm{X}+8.95$ & $\mathrm{Y}=0.38 \mathrm{X}-0.55$ & $\mathrm{Y}=1.4 \mathrm{X}+1.48$ & $\mathrm{y}=0.71 \mathrm{X}+0.41$ & $\mathrm{y}=0.59 \mathrm{X}+0.23$ & $\mathrm{y}=1.20 \mathrm{X}-0.14$ \\
\hline
\end{tabular}

Where $\mathrm{LC}_{50}, \mathrm{RT}, \mathrm{R}^{2}, \mathrm{Re} \mathrm{Eq}$ and $\mathrm{LT}_{50}$ are leathal concentration, relative toxicity, regression equation and leathal time respectively.

considerable mortality rate with mosquitoes, the presented results confirm the antagonistic effects on mosquitoes. Our results agree with Liu et al. (2014) who studied the combined effects of two antibiotics on Microcystis aeruginosa and suggested an antagonistic interaction at the median effect level. The explanation of these results is that AM and ER have different modes of action as reported above, besides the fact that the tested concentrations of the molecules were at very low levels. Moreover, the different molecular size (Fig. 1) and weight (Table 1) may limit each molecule to react independently with the sensitive site on the cell wall or nervous system of the fish or mosquitoes. Accordingly, an antagonistic effect was observed on fish and mosquitoes.

Our results agree with Orton et al. (2014), who observed complete suppression of dihydrotestosterone effects when chemicals were combined at individual concentrations eliciting $1 \%, 10 \%$ or $20 \%$ androgen receptor antagonistic effect. They also reported that the combined androgen receptor antagonistic effects occurred at very low concentrations of individual mixture components.

Furthermore, the molecules of antibiotics in the mixture tests tend to interact with each other and may form a larger molecule which geometrically cannot fit the interaction with sensitive site in the cell wall or the nervous system of fish or mosquitoes. Accordingly a reduction of mortality percentage was obtained. This explanation accords with previous published work (El-Nahhal \& Safi, 2004) which found that organic molecules dissolved into each other and formed a larger molecule that cannot react with the adsorption site due to steric effect. However, the mortality percentage obtained in mosquitoes (Fig. 4) clearly demonstrated that mosquito larvae are more sensitive to the tested antibiotics than fish. Moreover, our results agree with a recent report of Berger et al. (2014) who reported that exposure to an environmentally relevant mixture of contaminants results in development of abnormalities in the absence of apparent maternal toxicity.

However, the small size of mosquitoes makes them more sensitive to toxic substances. These results agree with a previous report (Kumar et al., 2010).

It is cleare from the results presented that fish and mosquitoes are sensitive to the tested antibiotics, accordingly they will die at low concentrations. Under these conditions, they become easy accessible food to the secondary and tertiary consumers in the eco-system. Accordingly, bioaccumulations of these antibiotics become a serious problem in the ecosystem. This hypothesis agrees with El-Amrani et al. (2012), who found different bioaccumulation modes of chemicals in Zebrafish eleutheroembryos. Moreover, the biodeterioration of dead fish and mosquitoes may result in a slow release of the antibiotics into the eco-system, accordingly the development of antibiotic-resistant genotypes may occur, and consequently antibiotics may lose their therapeutic effectiveness. Our suggestion is supported by the results of Poonia et al. (2014), who isolated antibiotic-resistant bacteria from natural sources of water where antibiotics are commonly used. More support for our suggestion comes from Mulamattathil et al. (2014) who isolated environmental bacteria from surface and drinking water that were resistant to antibiotics.

\section{CONCLUSION}

This study investigated the single and mixture toxicities of AM, ER, and EN on fish and mosquitoes as non-target organisms of the antibiotic. The study ranked AM the most toxic antibiotic to fish with $\mathrm{LC}_{50}$ value equals to $35.72 \mu \mathrm{g}$ $\mathrm{L}^{-1}$. EN and ER have $\mathrm{LC}_{50}$ vales for fish 89.32 and $242.7 \mu \mathrm{g}$ $\mathrm{L}^{-1}$ respectively. The relative toxicity of AM is lower than 1 indicating extreme toxicity, whereas the relative toxicity of ER is 2.6 indicating lower toxicity. ER is more toxic to mosquitoes than $\mathrm{AM}, \mathrm{LC}_{50}$ values are 60.2 and $107.6 \mu \mathrm{g}$ $\mathrm{L}^{-1}$ respectively. The relative toxicity of ER is 0.95 whereas that of AM is 1.7. Time response relationships (Table 3) are not similar and $\mathrm{LT}_{50}$ values ranged from 33.72-63.47 hours, indicating different exposure times are required to produce the toxic effect. Statistical analysis revealed significant differences in toxicities to fish and mosquitoes. Binary mixtures were less toxic to fish and mosquitoes than single toxicity, and did not produce a mortality rate greater than $60 \%$ in all cases.

\section{ACKNOWLEDGMENT}

Dr Y. El-Nahhal acknowledges Alexander von Humboldt Stiftung Foundation Fellowship Grant no IVPAL/1104842 STP, Germany. Special thanks go to Prof Dr G.lagaly at Kiel University, Prof Gerrit Schüürmann Germany. Special thanks also go to Mrs. Julie WebbPullman For her critical reading of the manuscript. 


\section{REFERENCES}

ABD RABOU A. N. 2005. An ecological survey and assessment of Wadi Gaza Nature Reserve, Gaza Strip - Palestine, with particular emphasis on wildlife. Ph.D. Thesis, Department of Environmental Studies, Faculty of Science and Technology, AlNeelain University - Sudan, P: 278.

AMBERG, J.J., SCHREIER, T.M. \& GAIKOWSKI, M.P. 2012. Molecular responses differ between sensitive silver carp and tolerant bighead carp and bigmouth buffalo exposed to rotenone. Fish Physiol. Biochem. 38:1379-1391. http://dx.doi. org/10.1007/s10695-012-9625-1.

BAUER, M., GREENWOOD, S.J., CLARK, K.F., JACKMAN, P. \& FAIRCHILD, W. 2013. Analysis of gene expression in Homarus americanus larvae exposed to sublethal concentrations of endosulfan during metamorphosis. Comp. Biochem. Physiol. Part D Genomics Proteomics. 8:300-308. http://dx.doi. org/10.1016/j.cbd.2013.07.002.

BERGER, G. R., LEFÈVRE, P., ERNEST, S., WADE, M., MA, Y., RAWN, D., GAERTNER, D., ROBAIRE, B. \& HALES, B. 2014. Exposure to an environmentally relevant mixture of brominatedflame retardants affects fetal development in SpragueDawley rats. Toxicol 320: 56-66. http://dx.doi.org/ 10.1016/j. tox.2014.03.005.

BRADBURY, S.P., RUSSOM, C.L. \& ANKLEY, G.T. 2003. Overview of data and conceptual approaches for derivation of quantitative structure-activity relationships for ecotoxicological effects of organic chemicals. Environ. Toxicol. Chem. 22:17891798.

BRASCHI, I., BLASIOLI, S., FELLET, C., LORENZINI, R., GARELLI, A., PORI, M. \& GIACOMINI, D. 2013. Persistence and degradation of new $\beta$-lactam antibiotics in the soil and water environment. Chemosphere, 93:152-159. http://dx.doi. org/10.1016/j.chemosphere.2013.05.016.

CARBALLEIRA, C., DE-ORTE, M. R., VIANA, I. G., DELVALLS, T. A. \& CARBALlEIRA, A. 2012. Assessing the toxicity of chemical compounds associated with land-based marine fish farms: the sea urchin embryo bioassay with Paracentrotus lividus and Arbacia lixula. Arch. Environ. Contam. Toxicol. 63:249261. http://dx.doi.org/10.1007/s00244-012-9769-0.

CHRISTENSEN, A. M., INGERSLEV, F. \& BAUN, A. 2006. Ecotoxicity of mixtures of antibiotics used in aquacultures. Environ. Toxicol. Chem. 25:2208-2215.

DE-ALWIS, H. G., GIRARD, L., KIJAK, P. J. \& RUMMEL N. 2013. Determination of erythromycin in medicated salmonid fish feed by liquid chromatography and UV spectroscopy. J. AOAC Int. 96:1233-1238.

DI-SAlVO, A. 1., DELlA-ROCCA, G., CAGNARDI, P. \& PELLEGRINO, R. M. 2013. Pharmacokinetics and residue depletion of erythromycin in rainbow trout Oncorhynchus mykiss (Walbaum). J. Fish. Dis. 36:1021-1029. http://dx.doi. org/10.1111/jfd.12074.

EBERT, I., BACHMANN, J., KÜHNEN, U., KÜSTER, A., KUSSATZ, C., MALETZKI, D. \& SCHLÜTER, C. 2011. Toxicity of the fluoroquinolone antibiotics enrofloxacin and ciprofloxacin to photoautotrophic aquatic organisms. Environ. Toxicol. Chem.30: 2786-2792. http://dx.doi.org/ 10.1002/ etc. 678 .

ECHEVERRÍA-SÁENZ, S., MENA, F., PINNOCK, M., RUEPERT, C., SOLANO, K., DE, L.A., CRUZ, E., CAMPOS, B., SÁNCHEZ-AVILA, J., LACORTE, S. \& BARATA, C. 2012. Environmental hazards of pesticides from pineapple crop production in the Río Jiménez watershed (Caribbean Coast,
Costa Rica). Sci. Total. Environ.440 : 106-114. http://dx.doi. org/10.1016/j.scitotenv.2012.07.092.

EL-AMRANI, S., PENA-ABAURREA, M., SANZ-LANDALUZE, J., RAMOS, L., GUINEA, J. \& CÁMARA, C. 2012. Bioconcentration of pesticides in Zebrafish eleutheroembryos (Danio rerio). Sci. Total. Environ. 425:184-190. http://dx.doi. org/ 10.1016/j.scitotenv.2012.02.065.

EL-NAHHAL, Y., NIR, S., POLUBESOVA, T., MARGULIES, L. \& RUBIN, B.1998. Leaching phytotoxicity and weed control of new formulations of alachlor. J. Agric. Food Chem. 46: 33053313.

EL-NAHHAL, Y. \& SAFI, J. 2004, Adsorption behavior of phenanthrene on organoclays under different salinity levels. J. Coll. Int. Sci. 269:265-273.

GAO, L., SHI, Y., LI, W., LIU, J. \& CAI, Y. 2012. Occurrence, distribution and bioaccumulation of antibiotics in the Haihe River in China. J. Environ. Monit. 14: 1248-1255. http://dx.doi. org/ 10.1039/c2em10916f.

GOZLAN, I., ROTSTEIN, A. \& AVISAR, D. 2013. Amoxicillindegradation products formed under controlled environmental conditions: identification and determination in the aquatic environment. Chemosphere 91:985-992. http://dx.doi. org/10.1016/j.chemosphere.2013.01.095.

HE, X., NIE, X., YANG, Y., LIU, X., PAN, D., CHENG, Z. \& LIANG, X. 2012. Multi-biomarker responses in fishes from two typical marine aquaculture regions of South China. Mar. Pollut. Bull.64 :2317-2324. http:// dx.doi.org/10.1016/j.marpolbul.2012.09.002.

JI, K., KIM, S., HAN, S., SEO, J., LEE, S., PARK, Y., CHOI, K., KHO, Y. L., KIM, P. G., PARK, J. \& CHOI, K. 2012. Risk assessment of chlortetracycline, oxy tetracycline, sulfamethazine, sulfathiazole, and erythromycin in aquatic environment: are the current environmental concentrations safe. Ecotoxicol. 21:20312050. http://dx.doi.org/ 10.1007/s10646-012-0956-6.

KARIM, A. A., HARIDI, A. A. \& EL-RAYAH, E. A. 1985. The environmental impacts of four insecticides on non-target organisms in the Gezira Irrigation Scheme canals of Sudan. J. Trop. Med. Hyg. 88:161-168.

KUMAR, M., AITKEN, J., CARVALHO, F., CULL-ENDER, T., MWANGI, S., SRINIVASAN, S., SITARAMAN, S., KNIGHT, R., LEY, R. \& GEWIRTZ, A. 2010. Metabolic Syndrome and Altered Gut Micro biota in Mice Lacking. Toll-Like Receptor. Sci.328: 228-231. http://dx.doi.org/ 10.1126/science.1179721.

LAMM, A., GOZLAN, I., ROTSTEIN, A. \& AVISAR, D. 2009.

Detection of amoxicillin-diketopiperazine-2', 5, in wastewater samples. J. Environ. Sci. Health A 44 :1512-1517. http://dx.doi.org/10.1080/10934520903263306.

LIU, C., WANG, H., JIANG, Y. \& DU, Z. 2011. Rapid and simultaneous determination of amoxicillin, penicillin $\mathrm{G}$, and their major metabolites in bovine milk by ultra-highperformance liquid chromatography-tandem mass spectrometry. J. Chromatogr. B. 879:533-540. http://dx.doi.org/10.1016/j. jchromb.2011.01.016.

LIU, J., LU, G., DING, J., ZHANG, Z. \& WANG, Y. 2014. Tissue distribution, bioconcentration, metabolism, and effects of erythromycin in crucian carp (Carassius auratus). Sci. Total. Environ. 490:914-920. http://dx.doi.org/10.1016/j.scitotenv.

LIU, Y., GAO, B., YUE, Q., GUAN, Y., WANG, Y. \& HUANG, L.2012. Influences of two antibiotics contaminants on the production, release and toxicity of microcystins. Ecotoxicol. Environ. Saf. 77: 79-87. http://dx.doi.org/ 10.1016/j. 
ecoenv.2011.10.027

LIU ,Y., ZHANG, J., GAO, B. \& FENG, S. 2014. Combined effects of two antibiotic contaminants on Microcystis aeruginosa. J. Hazard. Mater. 279:148-155. http://dx.doi.org/ 10.1016/j. jhazmat.2014.07.002.

MILAM, J., RICHARDSON, J. L., MCCUTCHAN, A., STOYANOFF, S., WEISS, J., KEMPER, C., LARSEN, R. A., HOLLANDER, H., WEISMULLER, P. \& BOLAN, R. 2005. Effect of a brief antiretroviral adherence intervention, delivered by HIV care providers. J. Acquir. Immune. Defic. Syndr.40: 356363.

MOH PALESTINIAN MINISTRY OF HEALTH, 2012. Annual report.

MOZAYANI, A., \& RAYMON, L. 2004. Handbook of Drug Interactions: A Clinical and Forensic Guide. Humana Press Inc. $2^{\text {nd }}$ Edition, New Jersey, P: 303.

MULAMATTATHIL, S. G., BEZUIDENHOUT, C., MBEWE, M. \& ATEBA C. N. 2014. Isolation of environmental bacteria from surface and drinking water in mafikeng, South Africa, and characterization using their antibiotic resistance profiles. J Pathog.2014:371208. http://dx.doi.org/10.1155/2014/371208.

NOVO, A., ANDRÉ, S., VIANA, P., NUNES, O. C. \& MANAIA, C. M. 2013. Antibiotic resistance, antimicrobial residues and bacterial community composition in urban wastewater. Water Res. 47:1875-1887. http://dx.doi.org/ 10.1016/j. watres.2013.01.010.

OECD.1984. Procedures to verify the toxicity of the tested compounds and their mixtures. www.oecd.org/dataoecd/17/20/1948241.

OECD. 1992. Guideline for testing of chemicals. Adopted by the Council on 17th July 1992. Fish, Acute Toxicity Test.

OLIVEIRA, R., MCDONOUGH. S., LADEWIG, J. C., SOARES, A. M., NOGUEIRA, A. J. \& DOMINGUES, I. 2013. Effects of oxytetracycline and amoxicillin on development and biomarkers activities of zebrafish (Danio rerio). Environ. Toxicol. Pharmacol. 36:903-912. http://dx.doi.org/10.1016/j. etap.2013.07.019

OPLINGER, R. W. \& WAGNER E. J. J. 2013. Control of Flavobacterium psychrophilum: Tests of Erythromycin, Streptomycin, Osmotic and Thermal Shocks, and Rapid $\mathrm{pH}$ Change. J. Aquat. Anim. Health. 25:1-8. http://dx.doi.org/10.108 0/08997659.2012.720636.

ORTON, F., ERMLER, S., KUGATHAS, S., ERIKA-ROSIVATZ, E., SCHOLZE, M. \& KORTENKAMP, A. 2014. Mixture effects at very low doses with combinations of anti-androgenic pesticides, antioxidants, industrial pollutant and chemicals used in personal care products. Toxicol. Appl. Pharmacol. 278:201208. http://dx.doi.org/10.1016/j.taap.2013.09.008.

PARK, E. K., JUNG, W. C. \& LEE, H. J. 2010. Application of a solid-phase fluorescence immunoassay to determine amoxicillin residues in fish tissue. Acta Vet. Hung. 58: 83-89. http://dx.doi. org/10.1556/AVet.58.2010.1.9.

POONIA, S., SINGH, T. S. \& TSERING, D. C.2014. Antibiotic susceptibility profile of bacteria isolated from natural sources of water from rural areas of East sikkim. Indian J Community Med. 39:156-160. http://dx.doi.org/10.4103/0970-0218.137152.
SAFI, J., EL-NAHHAL, Y., SOLIMAN, S. A. \& ELSEBAE, A. H. 1993. Mutagenic and carcinogenic pesticides used in the Gaza Strip Agricultural Environmental. Sci. Total Environ. 132:371380

SARMAH, A. K., MEYER, M. T. \& BOXALL, A. B. 2006. A global perspective on the use, sales, exposure pathways, occurrence, fate and effects of veterinary antibiotics (VAs) in the environment. Chemosphere. 65:725-759.

SCHLUSENER, M. P. \& BESTER, K. 2006. Persistence of antibiotics such as macrolides, tiamulin and salinomycin in soil. Environ. Pollut. 143: 565-571.

SMITH, S., GIESEKER, C., REIMSCHUESSEL, R., DECKER, C. S. \& CARSON, M. C. 2009. Simultaneous screening and confirmation of multiple classes of drug residues in fish by liquid chromatography-ion trap mass spectrometry. J Chromatogr A. 1216 :8224-8232. http://dx.doi.org/10.1016/j. chroma.2009.06.077.

SPRAGUE, J. B. \& RAMSAY, B. A. 1965. Lethal levels of mixed copper-zinc solutions for juvenile salmon. J. Fish. Res. Board Can.22:425-432.

TESTOlin, R. C., TISCHER, V., LIMA, A. O., COTELlE, S., FÉRARD, J. F. \& RADETSKI, C. M. 2012. Aquatic ecotoxicity assessment of a new natural formicide. Environ. Sci. Pollut. Res Int. 19:2186-2194. http://dx.doi.org/10.1007/s11356-0110721-z.

TOMLIN, E. S., ANTONEJEVIC, E., ALFARO, R. I. \& BORDEN, J. H. 2000. Changes in volatile terpene and diterpene resin acid composition of resistant and susceptible white spruce leaders exposed to simulated white pine weevil damage. Tree Physiol. 20: 1087-1095.

TONG, L., HUANG, S., WANG, Y., LIU, H. \& LI, M. 2014. Occurrence of antibiotics in the aquatic environment of Jianghan Plain, central China. Sci. Total Environ.497-498:180-187. http://dx.doi.org/10.1016/j.scitotenv.2014.07.068.

TYCZKOWSKA, K. L.,VOYKSNER, R. D., STRAUB, R. F. \& ARONSON, A. L. 1994. Simultaneous multiresidue analysis of beta-lactam antibiotics in bovine milk by liquid chromatography with ultraviolet detection and confirmation by electrospray mass spectrometry. JAOAC Int. 77:1122-1131.

U.S. CODE OF FEDERAL REGULATIONS. 1991. Part 21, Section 556.38, Amoxicillin; U.S. Government Printing Office, Washington, DC.

WANG, J. \& GARDINALI, P. R. 2012. Analysis of selected pharmaceuticals in fish and the fresh water bodies directly affected by reclaimed water using liquid chromatographytandem mass spectrometry. Anal. Bioanal. Chem. 9:2711-2720. http://dx.doi.org/10.1007/s00216-012-6139-8.

WANG, J., CHAO, R.M., CHANG, H.M. \& KUO, F.T. 2009. Liquid chromatographic determination of amoxicillin residues in grouper muscle following oral administration of the veterinary drug. Taiwan Vet. J. 35: 21-28.

YI, S. W., CHUNG, T. H., JOH, S. J., PARK, C., PARK, B. Y. \& SHIN, G. W. 2014. High Prevalence of blaCTX-M group Genes in Aeromonas dhakensis Isolated from Aquaculture Fish Species in South Korea. J. Vet. Med. Sci. 76:1589-1593. http://dx.doi. org/ 10.1292/jvms.14-0274. 